\title{
FRASA DAN KLAUSA PEMBANGUN DALAM NOVEL DIA ADALAH DILANKU TAHUN 1991 KARYA PIDI BAIQ
}

\section{CONSTRUCTING PHRASES AND CLAUSES IN THE NOVEL DIA ADALAH DILANKU TAHUN 1991 BY PIDI BAIQ}

\author{
Moh. Syaiful Huda \\ Program Studi Pendidikan Bahasa Indonesia \\ STKIP Al Hikmah Surabaya \\ Jalan Kebonsari Elveka V, Kec. Jambangan, Surabaya. \\ Pos-el: syaifulhuda155@gmail.com
}

*)Naskah diterima: 9 Juli 2020; direvisi: 9 Juli 2020; disetujui: 19 Juni 2021

\begin{abstract}
Abstrak
Bahasa dan sastra merupakan disiplin ilmu yang saling terkait. Kajian tentang bahasa biasa disebut dengan linguistik. Sintaksis merupakan salah satu cabang linguistik yang mengkaji bahasa berdasarkan struktur gramatikalnya. Frasa, klausa dan kalimat merupakan unsur yang dikaji di dalamnya. Tujuan dari penelitian ini 1) mendeskripsikan bentuk frasa dan klausa serta 2) fungsi frasa dan klausa sebagai unsur pembangun novel Dia Adalah Dilanku Tahun 1991 karya Pidi Baiq. Penelitian ini menggunakan metode kualitatif dengan model deskriptif-analisis. Hasil dari penelitian ini 1) mendeskrisikan bentuk frasa endosentris dan eksosentrik, dan klausa adjektif serta 2) fungsi frasa dan klausa sebagai unsur pembangun alur cerita dalam novel Dia Adalah Dilanku Tahun 1991 karya Pidi Baiq.
\end{abstract}

Kata kunci: sintaksis, frasa, klausa, novel

\begin{abstract}
Language and literature are interrelated disciplines. The study of language is known as linguistics. Syntax is a branch of linguistics that studies language based on its grammatical structure. Phrases, clauses and sentences are elements that are studied in it. The purpose of this study 1) to describe the form of phrases and clauses and 2) the function of phrases and clauses as the building blocks of the novel Dia Is Dilanku Tahun 1991 by Pidi Baiq. This study uses a qualitative method with a descriptiveanalytical model. The results of this study 1) describe the forms of endocentric and exocentric phrases, and adjective clauses and 2) the function of phrases and clauses as elements of the storyline in the novel Dia Is Dilanku Tahun 1991 by Pidi Baiq.
\end{abstract}

Keyword: syntax, phrases, clauses, novel 


\section{PENDAHULUAN}

Novel Dia Adalah Dilanku Tahun 1991 karya Pidi Baiq merupakan dwilogi dari Novel Dia Adalah Dilanku Tahun 1990. Novel terbitan Pastel Books Bandung 2016 dengan tebal 344 halaman bernomor ISBN: 978-6027870-99-4 ini menjadi novel populer pada tahun 2019. Novel ini bercerita kisah cinta Dilan dan Milea dari sudut pandang Milea. Milea Adnan Husain adalah orang yang berhasil menaklukkan hati seorang Dilan. Anak SMA sekaligus anggota geng motor.

Dilan merupakan kepala geng motor di sekolahnya. Ia digambarkan sebagai sosok yang keras kepala dan pemberontak. Namun, watak tersebut berbanding terbalik saat dia bertemu Milea. Dilan menjadi sosok yang romantis dan penuh kasih sayang. Sosoknya sebagai kepala geng motor dan pembuat onar di sekolah seketika lenyap saat dia bersama Milea. Perhatiannya, ketulusan hatinya, keluguannya membuat Milea tidak bisa melupakan sosok kekasihnya semasa SMA. Sampai pada akhirnya, kisah cinta itu berakhir. Sosok Dilan yang sangat dia cintai saat duduk di bangku sekolah dulu tidak ada lagi, bahkan saat pertemuan para alumni, Dilan yang biasanya datang ke sekolah penuh dengan semangat, kini tidak hadir. Orang yang paling Milea harapkan kehadirannya.

Tokoh Milea dalam novel tersebut digambarkan sebagai sosok yang juga romantis. Keduanya memiliki selera humor yang sama, meskipun sering kali berbeda dalam banyak hal. Perbedaan ini lah yang sering kali justru menciptakan suasana berubahubah. Terkadang menyenangkan, membahagiakan dan bahkan sering kali membuat Milea merasa cemas terhadap tingkah laku Dilan. Seperti pada kutipan berikut ini.

Aku betul-betul kesal ke dia! (Baiq, 2016: 146).
Berdasarkan struktur pembentuk kalimat tersebut, kutipan di atas merupakan bentuk klausa, karena hanya terdiri dari S $(a k u)+\mathrm{P}$ (betul-betul kesal ke dia!) dan tidak terdapat keterangan yang jelas tentang kesal karena alasan apa?

Selanjutnya, dalam penelitian ini akan mengkaji tentang struktur pembangun suatu bahasa. Kajian mengenai struktur bahasa adalah sintaksis. Kata sintaksis berasal dari Yunani, yakni "sun" serta "tatein", yang memiliki arti " menempatkan". Secara etimologis sintaksis berarti menempatkan bersama-sama kata dengan kata menjadi kelompok kata atau kalimat. Istilah sintaksis diperkenalkan pertama kali oleh Chomsky pada tahun 1957 melalui bukunya yang berjudul Syntactic Structure.

Istilah sintaksis menurut Abdul Chaer (2009: 60) merupakan sebuah tatanan linguistik umum yang membicarakan kata dalam hubugannya dengan kata lain atau unsur lain sebagai ujaran. Menurut Ramlan (2005: 138), sintaksis adalah bagian atau cabang ilmu bahasa yang membicarakan seluk beluk wacana, kalimat, frasa, dan klausa.

Berkaitan dengan frasa dan klausa, kedua unsur bahasan sintaksis tersebut memiliki definisi yang berbeda. Frasa sendiri merupakan satuan gramatikal yang terdiri dari dua unsur kata atau lebih dan bersifat nonpredikatif. Oleh karena itu, frasa merupakan gabungan kata yang tidak memiliki unsur predikat di dalamnya.

Frasa dapat terbagai menjadi dua bentuk, yaitu frasa endosentris dan frasa eksosentrik. Frasa endosentris ini merupakan frasa yang salah satu unsur keduanya adalah unsur inti atau pusat. Sedangkan frasa eksosentrik merupakan kebalikan dari endosentris, yaitu frasa yang tidak memiliki unsur inti dari kedua unsurnya. Sebagai contoh, berikut ini.

"Neil Armstrong pasti kecewa, udah capek-capek jadi Neil Armstrong, eh, 
gak pacaran sama kamu. Ngapain jauh-jauh ke bulan?" (Baiq, 2016: 73).

Kutipan novel tersebut terdiri atas frasa dan klausa. Pada aspek frasa terdapat pula frasa endosentris dan eksosentrik. (pacaran sama kamu), mtermasuk frasa endosentris dengan unsur pusat (sama kamu) dan (capek-capek, jauh-jauh, ke bulan) termasuk frasa eksosentrik.

Berdasarkan bentuk frasa tersebut sangat jelas bahwa frasa berbeda dengan klausa. Menurut Kridalaksana (2009: 21) klausa merupakan satuan gramatikal yang berupa gabungan kata yang bersifat predikatif. Klausa terdiri atas subjek dan predikat, yang mana dua unsur tersebut merupakan syarat minimal dari kalimat utuh.Sehingga klausa merupakan gabungan kata yang berpotensi menjadi kalimat.

Pada analisis ini, pembahasa dibatasi pada pembahasan tentang frasa dan klausa. Berdasarkan beberapa kutipan frasa dan klausa di atas, maka frasa dan klausa memiliki peran penting dalam membangun alur cerita pada novel Dia Adalah Dilanku Tahun 1991. Oleh karena itu, penulis tertarik mengambil judul "Frasa dan Klausa Pembangun Novel Dia Adalah Dilanku 1991 Karya Pidi Baiq".

Penelitian ini bertujuan untuk mendeskripsikan bentuk frasa dan klausa beserta fungsinya sebagai unsur pembangun novel. Penulis menggunakan studi sintaksis untuk menganalisis struktur bahasa dalam novel Dia Adalah Dilanku Tahun 1991 karya Pidi Baiq.

\section{LANDASAN TEORI}

\section{Frasa}

Frasa merupakan gabungan dua kata atau lebih yang bersifat non-predikatif. Kridalaksana (dalam Pehala, 2017: 129). Pendapat lain juga menyebutkan frasa adalah satuan gramatikal yang terdiri dari dua kata atau lebih yang tidak melampaui batasan fungsi yang terdapat dalam klausa (Ramlan, 2005: 138). Berdasarkan pendapat tersebut sangat jelas bahwa frasa berbeda dengan klausa. Frasa merupakan satuan lingual yang memiliki struktur inti dan modifier. Namun, tidak semua frasa terdiri dari struktur inti dan modifier. Seperti pada frasa nomina 'rumah kaca' yang menjadi inti dari frasa tersebut adalah nomina, yaitu 'rumah' dan 'kaca'. Frasa pada kelas kata terbuka hanya terdiri atas struktur inti, sedangkan pada frasa kelas kata tertutup yang menjadi inti adalah frasa kelas tertutup itu sendiri. Frasa pada kelas kata tertutup ialah, preposisi, determiner, numeral, komplemen, modal, negasi, kata hubung, dan kata kerja bantu. Matethews (1981: 161) dan Kridalaksana (1982: 46) menyebutkan adanya frasa adverbia, namun tidak menyebutkan adanya frasa determinan. Dia mendefinisikan frasa adverbia dimana adverbia sebagai induk dan adverbia lain sebagai modifier. Kridalaksana (dalam Pehala, 2017: 129).

\section{Klausa}

Klausa merupakan satuan gramatikal yang berupa gabungan kata yang bersifat predikatif. Klausa terdiri atas subjek dan predikat, yang mana dua unsur tersebut merupakan syarat minimal dari kalimat utuh sehingga klausa merupakan gabungan kata yang berpotensi menjadi kalimat (Kridalaksana, 1982: 85). Kalimat merupakan satuan bahasa yang berdiri sendiri, memiliki pola final yang secara faktual maupun potensial terdiri dari kalusa (Kridalaksana,1982: 71).

Dalam menganalisis frasa, maka dibutuhkan pemahaman terhadap fungsi, peran, dan kategori dalam kalimat.Hal ini bertujuan untuk mempermudah memahami unsur-unsur pembangun kalimat. Krida- 
laksana (1982: 48) menyebutkan bahwa fungsi merupakan peran sebuah unsur dalam satuan sintaksis yang lebih luas. Putrayasa (2014: 13) menjelaskan tentang peran, menurutnya, peran mengisi unsur fungsi yang berkaitan dengan makna gramatikal yang berupa pelaku, perbuatan, sasaran, dan tempat.Sedangkan untuk kategori. Putrayasa (2014: 48) menyebutkan bahwa kategori ialah frasa dan kelas kata seperti nomina, verba, preposisi, dan lainya. Kridalaksana (1982: 72) juga menjelaskan tentang kategori, menurutnya kategori merupakan satuan bahasa yang dibedakan atas bentuk fungsi dan makna, seperti kelas kata, jenis, kasus, kata, dan lainya.

Adapun ciri-ciri klausa adalah sebagai berikut: 1) dalam klausa terdapat satu predikat, tidak lebih dan kurang, 2) klausa dapat menjadi kalimat jika dalam pengucapannya menggunakan intonasi final, 3) klausa merupakan bagian dari kalimat, 4) klausa dapat diperluas dengan menambahkan fungsi-fungsi yang belum terdapat dalam klausa tersebut (Baehaqie dalam Darwin, 2017: 27).

Adapun macam-macam dari klausa tersebut menurut Tarigan (1986:3), sebagai berikut: 1) klausa independen, yaitu klausa yang dapat berdiri sendiri sebagai kalimat sempurna. Klausa independen berfungsi sebagai basis dan berkontruksi denga intonasi untuk membentuk suatu kalimat; 2) klausa intransitif, yaitu klausa yang tidak memiliki objek, klausa ini mengandung kata kerja intransitif, kata kerja yang tidak memerlukan objek. Klausa intransitif terdiri dari satu frase nomina (FN) dan satu frase verba intransitif (FVi); 3) klausa transitif, adalah kalusa yang mengandung kata kerja transitif yang mempunyai kapasitas satu objek atau lebih. Berbeda dengan klausa intransitif, klausa ini terdiri atas dua frasa nomina $(\mathrm{FN})$ dan satu verba transitif $(\mathrm{Vt})$, dan 4) klausa ekuatif, klausa yang ber- predikat verba ekuatif adalah klausa yang berisi verba ekuatif. Kalusa ini terdiri dari subjek (S) yang diisi oleh frase nomina, predikat $(P)$ yang diisi oleh frase verba ekuatif, dan komplemen (Komp) yang diisi oleh frasa nomina. (Tarigan dalam Darwin, 2017:28).

\section{METODE PENELITIAN}

Penelitian ini termasuk dalam model peneitian deskriptif-analisis. Metode ini digunakan dengan cara mendeskripsikan data-data yang disusul dengan analisis. Menggunakan analisis struktur kebahasaan sintaksis yaitu dengan mengidentifikasi unsur-unsur pembentuk suatu bahasa berupa frasa, klausa dan kalimat. Objek penelitian ini menggunakan novel karya Pidi Baiq, yaitu Novel Dia Adalah Dilanku Tahun 1991 yang diterbitkan oleh PT. Mizan Pustaka, tahun 2016. Pendekatan yang digunakan berfokus pada struktur internal novel Dia Adalah Dilanku Tahun 1991.

Metode yang digunkan dalam menyajikan analisis hasil data pada penelitian ini menggunakan metode formal dan informal. Metode formal artinya penyajian data menggunakan simbol-simbol tertentu, sedangkan metode informal berarti disajikan dengan uraian kata-kata. (Sudaryanto dalam Darwin, 2017:32).

Simbol-simbol yang dimaksudkan dalam metode formal adalah simbol yang terdapat dalam penulisan struktur frasa dalam kalimat. Misalnya seperti subjek maka dituliskan dengan simbol (S), predikat $(\mathrm{P})$, objek $(\mathrm{O})$, nomina $(\mathrm{N})$, adjectiva $(\mathrm{A})$, dan verba $(\mathrm{V})$. Sehingga penyajian data menjadi lebih sederhana.

\section{HASIL DAN PEMBAHASAN}

\section{Frasa}

Berdasarkan teori-teori yang telah disampaiakn pada bab di atas, frasa dapat di- 
definisikan sebagai satuan gramatikal yang terdiri dari dua kata atau lebih yang tidak melebihi batasan fungsi yang terdapat dalam klausa. Berikut ini merupakan kutipan yang terdapat dalam novel.

Malam ini, Minggu, tanggal 25 Januari 2015, pukul 22.19 waktu Indonesia bagian Barat dan sepi, aku sedang di kamarku, menikmati kopi susu, setelah tadi baru selesai shalat Isya, dan terus makan rambutan yang kubeli sepulang dari mengantar suamiku ke satasiun kereta api karena ada urusan pekerjaan di Cirebon. Sedangkan, anakku sudah tidur di kamarnya dari sejak pukul sembilan tadi. (Baiq, 2016: 13).

Pada kutipan novel tersebut dapat kita amati, terdapat beberapa frasa yang digunakan pengarang dalam bercerita., yaitu sebagai berikut.

a. kopi susu: gabungan dua kata yang tidak memiliki unsur predikatif. Kopi/susu merupakan unsur adjectiva atau kata benda. Menduduki unsur keterangan dalam kalimat.

b. satasiun kereta api: gabungan dua kata atau lebih yang tidak memiliki unsur predikatif. Stasiun/kereta/api merupakan unsur adjectiva atau kata benda. Menduduki unsur keterangan dalam kalimat.

Frasa preposisi dalam kutipan novel tersebut juga dapat dilihat dari kata 'sedang di kamarku', 'suamiku [ke stasisun]', 'pekerjaan di Cirebon', 'tidur di kamarnya'. Pada frasa preposisi tersebut, yang menjadi inti adalah preposisi (di) dan (ke). Preposisi menjadi inti, dan kata setelahnya menjadi modifier.Pada kasus tersebut preposisi tidak bisa beridiri sendiri sebagai suatu frasa, karena tergolong dalam frasa kelas kata tertutup.

Di luar sedang hujan dan angin berhembus cukup kencang. Mick Jagger lagi bersama Rolling Stones di dalam komputerku, menyanyikan lagu-lagu lamanya yang dengan cuaca Jakarta, setelah tadi membaca sebuah buku yang kuambila dari dalam laci mejaku, yaitu buku dengan judul: “Dilan, Dia adalah Dilanku, Tahun 1990". (Baiq, 2016: 14).

Pada kutipan novel sebelumnya telah berhasil menunjukkan unsur frasa yang terdapat dalam novel. Berikut ini juga merupakan kutipan dari novel Dia adalah Dilanku Tahun 1991. Pada kutipan tersebut juga terdapat frasa yang digunakan penulis dalam bercerita. Berikut pembahasannya.

Di luar sedang hujan dan angin berhembus cukup kencang. (Baiq, 2016:

14)

Kutipan tersebut terdiri atas sekumpulan frasa. Frasa 'di luar' termasuk dalam kelas kata tertutup, frasa preposisi. 'sedang hujan' termasuk frasa adverbia. Frasa terdiri atas 'sedang' dan 'hujan' merupakan gabungan dua kata yang menunjukkan makna hujan. Frasa tersebut termasuk dalam kelas kata terbuka, karena terdiri atas dua kata yang dapat berdiri sendiri.

Frasa adverbia lainya dalam kutipan novel tersebut juga terdapat dalam kata 'angin berhembus' yang merupakan kelas kata terbuka dari kata 'angin' dan 'berhembus'. Pada kutipan tersebut diakhiri dengan frasa adjektiva 'sangat kencang'. Oleh karena itu, dapat disimpulkan dalam kutipan novel tersebut bukan termasuk kalimat, melainkan kumpulan frasa.

Dan kata Piyan, malam itu Dilan sudah berkumpul dengan kawan-kawannya untuk melakukan balas dendam. (Baiq, 2016: 141). 
Pada kutipan ini juga terdapat frasa.Jika dianalisis tiap unsur kalimatnya, kutipan novel tersebut memiliki frasa sebagai berikut.

kata Piyan: merupakan salah satu contoh frasa eksosentrik. Frasa yang tidak memiliki unsur inti dari kedua unsurnya, dan tergolong dalam kelas kata terbuka.

Frasa preposisi dalam kutipan novel tersebut juga ada, dapat dilihat dari kata 'malam itu Dilan'. Pada frasa preposisi, preposisi menjadi inti, dan kata 'itu' adalah inti dari frasa tersebut, yang memarkahi kata 'malam' sehingga menunjukkan suatu malam yang dimaksutkan oleh penulis.

Ada pula frasa adverbia dalam kutipan tersebut ditunjukkan pada kata 'melakukan balas dendam'. Menurut Kridalaksana (1982: 46) frasa merupakan gabungan dua kata atu lebih yang bersifat non-predikatif. Sehingga pada kutipan tersebut, 'melakukan balas dendam' merupakan frasa yang terdiri dari tiga kata, 'melakukan', 'balas' dan 'dendam'.

Kata Dilan, semuanya ada 18 orang. Sebagian besar membawa motor sendiri. Mendadak malam itu, halaman depan rumahku menjadi seperti lapangan parkir. (Baiq, 2016: 106).

Dalam kutipan novel tersebut, terdapat frasa yang menyusun unsur kalimat. Dapat dilihat pada bagian kalimat 'sebagian besar', 'motor sendiri', 'malam itu', 'halaman depan rumahku', 'lapangan parkir'.

'Sebagian besar' tergolong sebagai frasa adjectiva, karena terdapat kata sifat sebagai salah satu unsur pembentuknya.

Frasa nomina terdapat pada bagian 'motor sendiri; 'halaman depan rumahku' dan 'lapangan parkir' karena pada bagian tersebut terdapat kata benda seabgai unsur penyusunnya.

Sedangkan pada 'malam itu' merupakan frasa preposisi. 'itu' menjadi inti frasa pre- posisi, dan merupakan frasa terikat. Frasa yang tidak dapat berdiri sendiri tanpa adanya unsur lain.

"Kang," kata Dilan ke Kang Adi. "maaf mengganggu. Sampai bawa banyak teman gini." (Baiq, 2016: 106).

Pada kutipan dialog tersebut, terdapat beberapa frasa yang digunakan oleh penulis dalam menggambarkan suatu dialog. Diantaranya 'maaf mengganggu' yang merupakan frasa adverbia.

\section{Klausa}

Klausa merupakan satuan gramatikal yang berupa gabungan kata yang bersifat predikatif. Klausa terdiri dari subjek dan predikat, yang mana dua unsur tersebut merupakan syarat minimal dari kalimat utuh sehingga klausa merupakan gabungan kata yang berpotensi menjadi kalimat.

"Ada Kang Adi," kataku ke Dilan dengan suara jangan sampai Kang Adi dengar. "Aku males nemui," kataku lagi dengan nada mengeluh. (Baiq, 2016: 97).

Penulis menggunakan klausa dalam bercerita. Pada kutipan novel tersebut, terdapat klausa yang membangun kalimat pada cerita.

Kang Adi dengar: kutipan tersebut berisi unsur pembangun kalimat berupa $S+P$. kang Adi (S) dengar (P). Hal tersebut sejalan dengan pendapat Kridalaksana (dalam Pehala, 2017:29) yang menyebutkan bahwa klausa sekurang-kurangnya terdiri atas dua unsur kalimat, yaitu subjek dan predikat $(\mathrm{S}+\mathrm{P})$.

Kataku lagi dengan nada mengeluh: kutipan tersebut berisi unsur pembangun kalimat berupa S+P. Kataku (S) lagi dengan nada mengeluh $(\mathrm{P})$.

Aku bilang ke Dilan bahwa kemarin waktu Piyan dan Wate ke rumahku, 
mereka cerita banyak tentang Dilan, dan aku senang. (Baiq, 2016: 95).

Pada kutipan sebelumnya juga ditemukan klausa yang menyusun unsur kalmat dalam cerita. Pada kutipan novel di atas terdapat klausa sebagai berikut:

Kata 'aku' merupakan frasa nomina, 'bilang' verba transitif, 'ke Dilan' sebagai unsur yang menduduki keterangan (K) berupa frasa preposisi. Sehingga termasuk dalam klausa intransitif, klausa yang terdiri dari satu frasa nomina dan satu verba transitif $(\mathrm{Vt})$.

Piyan bicara sedikit agak gugup.Dia memberi kabar bahwa Dilan sudah tahu siapa yang mengeroyoknya tempo hari di warung Bi Eem. (Baiq, 2016: 141).

Pada kutipan tersebut juga terdapat klausa yang menjadi unsur pembangun kalimat dalam cerita. Klausa tersebut dapat dilihat dari 'Piyan bicara sedikit agak gugup' dan 'Dilan sudah tahu'.Pada kutipan tersebut kata Piyan memiliki kedudukan sebagai unsur (S) dan bicara sedikit agak gugup memiliki kedudukan sebagai unsur (P).

Sedangkan 'Dilan sudah tahu' memiliki kedudukan sebagai klausa, dimana kata 'Dilan' kedudukannya sebagai unsur subjeh (S) dan sudah tahu memiliki kedudukan sebagai predikat $(\mathrm{P})$.Sehingga kalusa tersebut berpotensi menjadi kalimat, dan berarti 'Dilan' sudah tahu terhadap maksut yang ingin penulis sampaikan.

Aku berjalan di belakang Dilan sambil memegang ujung belakang kemejanya. (Baiq, 2016: 106).

Bagian yang ditebalkan pada kutipan tersebut termasuk klausa. 'aku' menduduki unsur subjek (S) termasuk frasa nomina, 'berjalan' predikat, atau kata kerja, dan 'di belakang Dilan' termasuk frasa preposisi karena kedudukannya sebagai unsur keterangan (K) dalam kalimat.

Aku naik mobil Yugo. Kuarahkan

Yugo untuk masuk ke Jalan Buah Batu.

Terus, lurus menuju Supermarket

Trina. (Baiq, 2016: 144).

Pada kutipan novel tersebut dapat diambil klausa yang menyususn unsur kaliamt dalam cerita. Berikut:

Aku naik mobil Yugo

'Aku' pada kalimat tersebut merupakan unsur frasa nomina (FN), 'naik' termasuk dalam verba transitif (Vt), 'mobil Yugo' berkedudukan sebagai frasa nomina (FN). Sehingga pada struktur kalimat tersebut merupakan klausa transitif. Klausa yang terdiri dari dua frasa nomina (FN) dan satu verba transitif $(\mathrm{Vt})$.

Bang Faris tidak menjawab. (Baiq, 2016: 126)

Bang Faris diam, seperti orang menahan untuk bicara. (Baiq, 2016: 126)

Bang Faris masih diam. Tapi aku tahu dia sedang menyimak kata-kataku. (Baiq, 2016: 126)

Bang Faris tetap diam. Sepertinya dia bingung mau ngomong. (Baiq, 2016: 126)

Bang Faris diam, berusaha bersikap akomodatif. (Baiq, 2016: 127)

Bang Faris masih diam. (Baiq, 2016: 127)

Bang Faris ketawa. (Baiq, 2016: 127).

Kutipan novel tersebut memiliki keunkian tersediri dalam penggunaan klausa. Penulis secara berturut-turut menggunakan pola klausa yang sama. 'Bang Faris tidak menjawab' terdiri dari unsur subjek (S) yang 
kedudukannya sebagai frasa nomina, 'tidak menjawab' mengisi unsur predikat $(\mathrm{P})$ merupakan verba transitif.

'Bang Faris diam' juga memiliki pola yang sama dengan pola klausa sebelumnya. Yaitu 'Bang Faris' menduduki unsur subjek (S) dalam kalimat, 'diam' menduduki unsur predikat (P). Maka jika kedua kaluasa tersebut memiliki struktur S+P dalam pembentukannya.

Pada klausa berikutnya, juga memiliki pola klausa yang sama. Yaitu terdiri dari $\mathrm{S}+\mathrm{P}$, sehingga pada kutipan novel tersebut, penulis menggunakan klausa intransitit secara berturut-turut dalam bercerita.

Aku duduk di kursi yang ada di samping Ibuku. (Baiq, 2016: 130)

Kutipan novel tersebut memiliki unsur klausa dalam pembentukan kalimatnya. 'aku' sebagai subjek (S) termasuk nomina. 'duduk' sebagai unsur predikat (P) dan 'di kursi' yang menduduki unsur keterangan dalam kalimat menyandang frasa preposisi. Sehingga pada klausa tersebut merupakan klausa intransitif, karena terdiri dari satu (FN) dan satu (Vt).

Aku bercerita tentang Bandung.Dan ini artinya, aku langsung ingat Dilan. (Baiq, 2016: 134).

Kutipan novel tersebut menunjukkan adanya klausa dalam unsur pembentuk kalimat. Berikut pembahasannya, 'aku' sebagai unsur subjek (S) merupakan nomina, 'bercerita' sebagai predikat $(\mathrm{P})$ dan 'tentang Bandung' memegang unsur keterangan (K) merupakan frasa preposisi.

Aku naik angkot sesuai petunjuk orang yang kutanya. (Baiq, 2016: 175).

Bagian yang ditebalkan tersebut merupakan klausa yang terdiri atas satu nomina dan satu verba transitif. Sedangkan kata 'angkot' menduduki unsur keterangan (K). Kedua klausa dari kutipan novel tersebut merupakan klausa intransitif.

\section{PENUTUP}

Kajian bahasa utamanya sintaksis dapat diterapkan dalam beberapa kajian sastra, utamanya untuk mengkaji penggunaan struktur dari suatu bahasa. Frasa merupakan struktur terkecil dalam kajian sintaksis dan klausa sebagai satuan kata yang lebih besar. Novel Dia Adalah Dilanku Tahun 1991 Karya Pidi Baiq memiliki keunikan dalam penggunaan frasa dan klausa.

Frasa dan klausa digunakan dalam menceritakan kisah cinta Milea terhadap Dilan. Frasa endosentris dan eksosentrik banyak digunakan dalam dialog yang terjadi antartokoh, mendeskripsikan latar cerita, dan memunculkan konflik. Sementara itu, klausa adjektiva digunakan untuk mendeskripsikan perasaan tokoh.

Pada akhirnya, kesimpulan analisis tersebut, yaitu: 1) mendeskripsikan bentuk frasa endosentris dan eksosentrik, bentuk klausa adjektifa serta; 2) fungsi frasa dan klausa sebagai unsur pembangun novel Dia Adalah Dilanku Tahun 1991 karya Pidi Baiq.

\section{DAFTAR PUSTAKA}

Baiq, Pidi. 2016. Dia Adalah Dilanku Tahun 1991. Bandung: Pastel Book.

Chaer, Abdul. 2009. Sintaksis Bahasa Indonesia (Pendekatan Proses). Jakarta: Rineka Cipta.

Darwin. 2017. Struktur Klausa Independen Bahasa Dondo. Sulawesi Tengah: FKIP Universitas Tadulako. Jurnal Bahasa dan Sastra Volume 2 No 2 (2017) ISSN 23022043.

Haryanti, ND. 2019. Pola Narasi pada Antologi Cerpen Tarian Salju Karaban. DIALEKTIKA 6(1), 95113

Kridalaksana, Harimurti. 2009. Pembentukan Kata dalam Bahasa Indonesia. Jakarta: PT 
Gramedia Pustaka Utama.

Lahu, Ovina Elvira. 2014. Kalusa Sifat dalam Jurnal English Teaching Forum Volume 47 No. 2 Tahun 2009. Manado: Universitas Ratulangi.

Mulyadi. 2010. Frase Preposisi Bahasa Indonesia: Analisis X-Bar. Kajian Sastra: Jurnal Bidang Kebahasaan dan Kesusastraan Vol.34, No.1 2010. E-journal Undip

Pehela, I.A. 2017. Frasa dan Klausa dalam Kata Polisintesis pad Bahasa Tolaki. Center of Language and Culture Studies: Surakarta. Jurnal LINGUA Vol.14, No.2, e-ISSN:
2442-238X.

Ramlan. 2005. Sintaksis. Yokyakarta: CV. Karyono.

Tarigan, H. G. 1984. Metode dan Aneka Teknik Analisis Bahasa. Yogyakarta: Ar-Ruzz Media.

Tarigan, H. G. 1984. Pengajaran Sintaksis. Bandung: Angkasa. 